\title{
Impact of oral health conditions on the quality of life of quilombola and non-quilombola rural adolescents in the countryside of Bahia, Brazil: a cross-sectional study
}

\author{
Etna Kaliane Pereira da Silva* ${ }^{*}$ and Danielle Souto de Medeiros
}

\begin{abstract}
Background: This study aimed to estimate the prevalence of negative impacts of oral health conditions on the quality of life of quilombola and non-quilombola rural adolescents and identify associated factors.

Methods: This cross-sectional study was carried out in a rural area in the countryside of Bahia, Brazil, in 2015. Participants were asked to complete the Oral Impacts on Daily Performance Questionnaire. Prevalence and prevalence ratios (PR) were estimated together with their respective $95 \%$ confidence intervals. Multiple analysis was conducted using Poisson regression with robust error variance and hierarchical entry of variables.

Results: Of the 390 rural adolescents who took part in the study, $42.8 \%$ were quilombolas, and $45.6 \%$ of all participants reported a negative impact of their oral health conditions on their quality of life. The most prevalent impact was difficulty eating (32.6\%). After adjusted analysis, the following factors were found to be associated with the negative impact of oral health conditions on quality of life: age $(P R=1.04)$, feeling lonely ( $P R=1.42)$, worst evaluation of oral health $(P R=1.52)$, need of dental care $(P R=1.33)$, and occurrence of toothache in the last 6 months $(P R=1.83)$. Quilombolas and non-quilombolas presented with a different prevalence of discomfort when brushing their teeth and had different factors associated with the negative impact of oral health conditions on their quality of life. Both quilombola and non-quilombola rural adolescents showed a high prevalence of negative impact of oral health conditions on their quality of life.
\end{abstract}

Conclusions: These results support the need for improved oral healthcare for specific populations like the quilombolas. Furthermore, the results illustrate the importance of incorporating oral healthcare strategies that take into consideration the sociocultural context of adolescents.

Keywords: Oral health, Quality of life, Adolescents, Rural health, African continental ancestry group

*Correspondence: etnakaliane@gmail.com

Instituto Multidisciplinar em Saude, Campus Anisio Teixeira, Universidade Federal da Bahia. Rua Hormindo Barros, 58, quadra 17, lote 58, Candeias,

Vitória da Conquista, BA 45029-094, Brazil

\section{Background}

Oral health is integral to general health and is a determinant factor for quality of life [1]. For adolescents, associations between oral health, general health, and quality of life are strongest, as this group is the most sensitive to the negative impacts of oral health

(c) The Author(s) 2020. This article is licensed under a Creative Commons Attribution 4.0 International License, which permits use, sharing, adaptation, distribution and reproduction in any medium or format, as long as you give appropriate credit to the original author(s) and the source, provide a link to the Creative Commons licence, and indicate if changes were made. The images or other third party material in this article are included in the article's Creative Commons licence, unless indicated otherwise in a credit line to the material. If material is not included in the article's Creative Commons licence and your intended use is not permitted by statutory regulation or exceeds the permitted use, you will need to obtain permission directly from the copyright holder. To view a copy of this licence, visit http://creativeco mmons.org/licenses/by/4.0/. The Creative Commons Public Domain Dedication waiver (http://creativecommons.org/publicdomain/ zero/1.0/) applies to the data made available in this article, unless otherwise stated in a credit line to the data. 
conditions on a range of aspects, including the perception of physical appearance and pain [2].

Oral health conditions can interfere with the psychological development and social interactions of adolescents [3]. Also, daily activities can be affected. For example, adolescents may experience discomfort when brushing their teeth and difficulty eating and/or speaking [2]. Socio-dental indicators are often used to measure the negative impact of oral health conditions on quality of life because they reflect individuals' selfperceptions and because clinical criteria alone do not permit a holistic evaluation of the impact of oral health conditions on daily life [4].

A study of Brazilian urban adolescents between 15 and 19 years of age found that $39.4 \%$ reported at least one negative impact of oral health conditions on daily life [2]. A higher prevalence of negative impact was found in international studies, varying from 54.6 to $66.8 \%$ [5-7]. This impact in the quality of life of adolescents has been associated not only with oral diseases and complications, like untreated cavities, tooth loss, toothache, periodontal disease, and malocclusion, but also with individual characteristics, including gender, race, and economic conditions [2, 3, 8].

Hardships, such as difficulty accessing education and health services and unfavourable socioeconomic conditions, can influence an individual's oral health status and healthcare utilisation, which can in turn negatively impact their quality of life. Adolescents who live in rural areas are exposed to different cultural influences and are subject to social vulnerabilities and health inequities. Among them, there are groups, like quilombola adolescents, with greater vulnerability [9].

Quilombolas are traditional Brazilian people with a presumption of black ancestry who keep alive their cultural and religious traditions, kinship, and identity marked by resistance to oppression, the denial of their rights, and racial segregation. Quilombola adolescents have a lower prevalence of dental consultations when compared to other rural adolescents. In addition, they reside in communities with greater social vulnerabilities, such as a precarious sanitised water supply, irregular garbage collection, low education level, and low family income $[10,11]$.

Studies on the negative impact of oral health conditions on adolescents' quality of life do not include adolescents who live in rural areas or traditional communities, like quilombola communities. Considering that the living environment influences individuals' oral health [12], this study aimed to estimate the prevalence of negative impact of oral health conditions on quality of life and identify associated factors in quilombola and non-quilombola adolescents in a rural area in the countryside of Bahia, Brazil.

\section{Methods}

This cross-sectional and population-based study was part of the research project ADOLESCER: Saude do Adolescente da Zona Rural e seus Condicionantes, which was carried out in 2015. Subjects were adolescents between 10 and 19 years of age who lived in 21 quilombola rural communities, all of them recognised by the Fundacao Cultural Palmares, and non-quilombola rural communities in Vitoria da Conquista, Bahia, Brazil.

The research was approved by the ethics committee for research on human beings in the Multidisciplinary Institute of Health of Bahia Federal University (Comite de Etica em Pesquisa com seres humanos do Instituto Multidisciplinar em Saude da Universidade Federal da Bahia) under report number 639.966. All of the participants were previously informed on the research goals, procedures, and data confidentiality through the Free and Informed Consent Form (Termo de Consentimento/ Assentimento Livre e Esclarecido) and expressed their agreement to participate in this study through signature or automated fingerprint identification.

To carry out the population estimate, we collected data from Brazilian Primary Health Care forms, used by the community health workers during the household visits. At the time of the study, $97.4 \%$ of the rural area of Vitoria da Conquista was covered by the Program of Community Health Workers.

To ensure viability and representativeness of the research, the sampling strategy took into account the territorial extension of rural communities and populations of adolescents. The sampling principles used were as follows: (1) the number of homes was selected proportionally to the number of adolescents per community, and (2) only one adolescent was interviewed per home. Moreover, in order to obtain valid estimates for quilombola and non-quilombola populations, the sample size was calculated separately for each stratum.

The sample size calculation was carried out using the following criteria: a prevalence of $50 \%$, given the heterogeneity of the events measured in the main project; an accuracy of 5\%; a confidence level of 95\%; a design effect equal to 1.0; and an addition of $15 \%$ for possible losses. However, as only one adolescent per home was interviewed, and because the number of homes was smaller for the quilombola communities, $7.1 \%$ of losses were added to the quilombola stratum. The presence of severe mental disorders among adolescents was used as an exclusion criterion.

Sampling for non-quilombola adolescents was carried out in two stages: (1) random selection of homes with 
adolescents, according to the proportional distribution of adolescents per community, and (2) random selection of adolescents in each home. For the quilombola sample, only random selection of adolescents in each home was used. All adolescents had the same probability of inclusion in the study.

The instrument used for the interview was a questionnaire with objective questions that have been described in previous surveys conducted in Brazil: National Oral Health Survey (Pesquisa Nacional de Saude Bucal, SBBrasil) [13], National School Health Survey (Pesquisa Nacional de Saude do Escolar, PeNSE) [14], and Health National Research National Health Survey (Pesquisa Nacional de Saude, PNS) [15]. The questionnaire was divided in two sections: (1) the first section was answered by the adolescents ( $\geq 18$ years) or their parents/guardians, and had questions about the general characteristics of their household and income and education of the head of the family; (2) the second section was answered by the investigated adolescent; it had questions about their characteristics and social support, job, lifestyle, perception of health status and body self-image, use of illicit drugs, sexual and reproductive health, oral health and hygiene, and use of health services.

The instrument underwent occasional modifications for adaptation in rural contexts; however, the original structure of the validated questionnaires was maintained to guarantee the reliability and comparability of the information. The final version was submitted to a pre-test and a pilot study to adapt to the following: (1) language (adaptations in terms of vocabulary); (2) sequence and coherence between the questions; (3) instructions on the questions to be skipped; and (4) the time required to conduct the interview.

Before data collection, the households and social facilities of the communities were mapped and the residents were sensitized to the research. The sample collection took place between January and May 2015. To guarantee the quality of the collected data, a second interview was conducted with $5 \%$ of the sample within 7 days of the first interview.

The outcome variable of this study was the negative impact of oral health conditions on quality of life, and it was measured using the Brazilian version used in the National Oral Health Survey [13] of Oral Impact on Daily Performance (OIDP) index [16]. This version was translated, adapted, and validated for use in Brazilian Portuguese. It has a Cronbach's $\alpha$ of 0.78 [95\% confidence interval (CI) 0.77-0.79] and has been used in Brazilian population-based studies [2, 17-19].

The OIDP assesses the impact of oral health conditions on eight daily activities, which cover physical (difficulty to eat, discomfort when brushing tooth, difficulty to speak), psychological (sleeping troubles, embarrassment when smiling, nervousness, and irritation), and social (problems with studying, interference in leisure) dimensions [16]. Each item was preceded by the question, 'Some people have problems that may have been caused by their teeth. From the situations given below, which ones apply to you in the last six months?' The answer provided were no and yes [16]. The OIDP was analysed as a dichotomous variable: absence of impact (total OIDP $=0$ ) or presence of impact (total OIDP $\geq 1$ ). A positive answer to at least one of the eight items of the index was considered "yes". We analysed the OIDP as a dichotomous variable because the distribution of the OIDP scores demonstrated two distinct groups. In addition, the conceptual approach supports this cut-off point, which has been used in previous studies with adolescent populations $[5,18,20]$.

The independent variables of this study were selected based on the conceptual model proposed by Petersen [21], in which the first section is formed by sociocultural and environmental factors and the second section by variables related to the utilisation of dental services and oral health risk behaviours (Fig. 1).

The chosen sociocultural characteristics were as follows: living in a quilombola community (yes; no), economic level ( $\mathrm{B}$ and $\mathrm{C}$-higher levels; $\mathrm{D}$ and $\mathrm{E}$-lower levels) [22]; gender (female; male); age (years); schooling (years of study); tobacco use (no; yes); illicit drug use (no; yes); practice of physical exercise $(<300 \mathrm{~min} /$ week; $\geq 300 \mathrm{~min} /$ week); close friends (up to 2 friends; more than 3 friends); family composition (adolescents living with their parents; adolescents not living with their parents); feelings of loneliness in the last 12 months (never/rarely; sometimes; often/always); and parents who were understanding of their personal issues in the last 30 days (often or always; sometimes; never or rarely).

The chosen environmental factors were as follows: the nutritional status obtained through standard measures for weight and height and body mass index (BMI) classified according to gender and age (thinness; eutrophy; overweight/obesity) [23]; and handwashing before meals (often or always; sometimes; never/rarely).

To characterise the utilisation of dental services, the following variables were used: self-assessment of oral health (very good/good; regular; bad/very bad); perception of a need for dental treatment (no; yes); toothache in the last 6 months (no; yes); and dental consultation in the last year (yes; no). In addition, oral health risk behaviours considered were: tooth brushing less than 3 times a day; no use of dental floss; regular consumption ( $\geq 5$ days per week) of unhealthy snacks and soft drinks.

The prevalence of negative impacts on each daily performance and the occurrence of at least one 


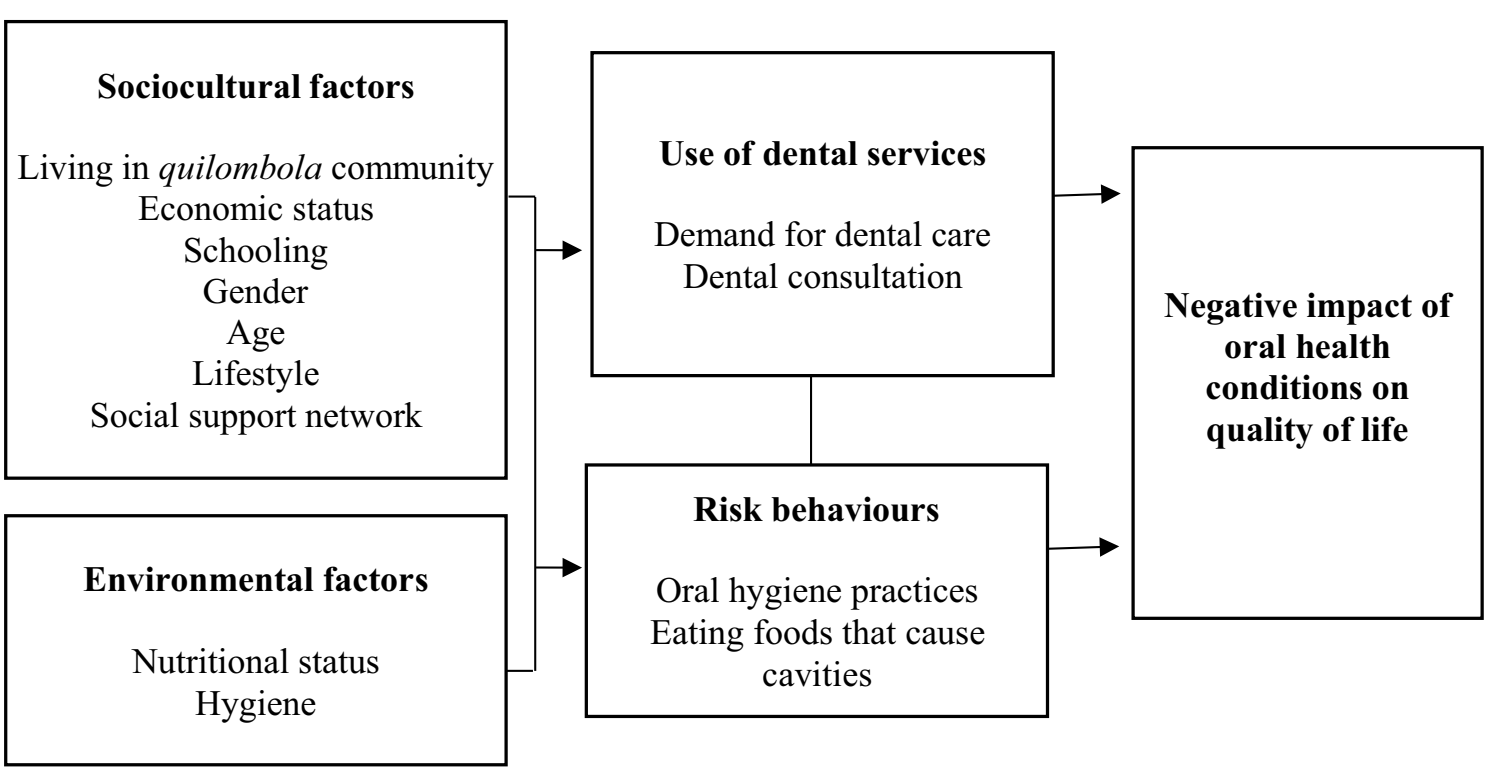

Fig. 1 Conceptual model for multiple analysis, adapted according to Petersen [21]

negative impact of oral health conditions on quality of life were evaluated for non-quilombolas, quilombolas, and the total sample. Prevalence differences between quilombolas and non-quilombolas were evaluated using the Pearson chi-squared test. For all tests, a significance level of $5 \%(P<0.05)$ was considered statistically significant.

Prevalence ratios and their respective 95\% confidence intervals, as estimated by Poisson regression with robust variance, were used to identify variables associated with the occurrence of negative impact of oral health conditions on quality of life in the total sample and the nonquilombola and quilombola samples. This model was chosen because it directly estimates the prevalence ratios, which is more appropriate due to the high prevalence of the analysed outcome [24]. All variables with a significance level of $20 \%$ in the bivariable analysis were included in the multiple analysis.

The multiple analysis was conducted using a hierarchical entry of the variables, initially including the set of sociocultural and environmental variables and later the set of variables related to the use of dental services and oral health risk behaviours. The variables of the first set were used as adjustment factors for the second set of variables. To compare the models, the Akaike information criterion (AIC) and Bayesian information criterion (BIC) were used, and the adjustment of the predicted values to the observed values was evaluated by the chi-squared test. The Stata software version 15.0 (Stata Corporation, College Station, USA) was used for data analysis.

\section{Results}

Of the 390 adolescents who were interviewed, $42.8 \%$ lived in quilombola communities. Differential losses were observed in relation to gender, with greater predominance in males between non-quilombola adolescents $(P=0.038)$. However, estimates with and without the calibration factor showed no significant differences. Thus, the analyses were conducted without considering the differential losses.

Most of the adolescents who participated in the survey had lower economic statuses and were female, physically inactive, had three or more close friends, lived with both parents, never or rarely felt alone, were mostly understood by their parents, were eutrophic, had a habit of washing their hands before meals, considered their oral health to be good or very good, consulted a dentist during the past year, and did not try tobacco or illicit drugs (Table 1).

However, $48.1 \%$ of the participants stated the need for dental treatment, and $19.6 \%$ reported dental pain in the last 6 months. Regarding oral health risk behaviours, $33.3 \%$ brushed their teeth fewer than three times a day; $46.7 \%$ did not floss; and $35.1 \%$ and $6.7 \%$ regularly consumed sweets and sodas, respectively. Significant differences between non-quilombolas and quilombolas were observed only in their economic status level (Table 1).

The prevalence of negative impacts of oral health conditions among rural adolescents were difficulty eating (32.6\%), sleeping troubles (14.1\%), nervousness and irritation (13.8\%), embarrassment when smiling (11.8\%), and tooth brushing discomfort (10.5\%). Differences among 
Table 1 Descriptive characteristics of participants in the total sample, quilombola and non-quilombola, stratified according to negative impact of oral health condition on the quality of life. Bahia, 2015

\begin{tabular}{|c|c|c|c|c|c|c|c|c|c|}
\hline \multirow[t]{3}{*}{ Variables } & \multicolumn{3}{|c|}{ Total sample } & \multicolumn{3}{|c|}{ Non-quilombola } & \multicolumn{3}{|c|}{ Quilombola } \\
\hline & \multirow[t]{2}{*}{$N(390)$} & \multicolumn{2}{|l|}{ Impact $^{\mathrm{a}}$} & \multirow[t]{2}{*}{$N(223)$} & \multicolumn{2}{|l|}{ Impact $^{a}$} & \multirow[t]{2}{*}{ n (167) } & \multicolumn{2}{|l|}{ Impact $^{\mathrm{a}}$} \\
\hline & & No (212) & Yes (178) & & No (117) & Yes (106) & & No (95) & Yes (72) \\
\hline \multicolumn{10}{|l|}{ Sociocultural factors } \\
\hline \multicolumn{10}{|l|}{ Economic status (\%) } \\
\hline B and C & 38.7 & 35.8 & 42.1 & $49.8^{n}$ & 46.1 & 53.7 & $23.9^{\natural}$ & 23.2 & 25.0 \\
\hline $\mathrm{D}$ and $\mathrm{E}$ & 61.3 & 64.2 & 57.9 & $50.2^{n}$ & 53.9 & 46.2 & $76.0^{\natural}$ & 76.8 & 75.0 \\
\hline \multicolumn{10}{|l|}{ Gender (\%) } \\
\hline Female & 51.3 & 50.0 & 52.8 & 48.9 & 47.9 & 50.0 & 54.5 & 52.6 & 56.9 \\
\hline Male & 48.7 & 50.0 & 47.2 & 51.1 & 52.1 & 50.0 & 45.5 & 47.4 & 43.1 \\
\hline Age, $(\text { median })^{b}$ & 14.8 & 14.3 & 15.3 & 14.6 & 14.5 & 14.7 & 15.0 & 14.2 & 16.0 \\
\hline Schooling (median) ${ }^{c}$ & 6.0 & 6.0 & 7.0 & 7.0 & 7.0 & 7.0 & 6.0 & 6.0 & 7.0 \\
\hline Trying tobacco (\%) & 5.1 & 3.3 & 7.3 & 5.4 & 3.4 & 7.5 & 4.8 & 3.2 & 6.9 \\
\hline Trying illicit drugs (\%) & 1.8 & 1.9 & 1.7 & 2.2 & 1.7 & 2.8 & 1.2 & 2.1 & 0.0 \\
\hline \multicolumn{10}{|l|}{ Practice of physical activities (\%) } \\
\hline Less than $300 \mathrm{~min} /$ week & 54.1 & 57.5 & 50.0 & 54.7 & 58.1 & 50.9 & 53.3 & 56.8 & 48.6 \\
\hline More or equal $300 \mathrm{~min} /$ week & 45.9 & 42.4 & 50.0 & 45.3 & 41.9 & 49.1 & 46.7 & 43.2 & 51.4 \\
\hline \multicolumn{10}{|l|}{ Close friends (\%) } \\
\hline Up to 2 friends & 16.9 & 17.0 & 16.8 & 17.5 & 17.9 & 17.0 & 16.2 & 15.8 & 16.7 \\
\hline 3 or more & 83.1 & 83.0 & 83.2 & 82.5 & 82.1 & 83.0 & 83.8 & 84.2 & 83.3 \\
\hline \multicolumn{10}{|l|}{ Family composition (\%) } \\
\hline Live with parents & 67.7 & 69.3 & 65.7 & 70.4 & 71.8 & 68.9 & 64.1 & 66.3 & 61.1 \\
\hline Do not live with parents & 32.3 & 30.7 & 34.3 & 29.6 & 28.2 & 31.1 & 35.9 & 33.7 & 38.9 \\
\hline \multicolumn{10}{|l|}{ Feeling lonely (\%) } \\
\hline Never or rarely & 63.3 & 70.3 & 55.7 & 62.8 & 70.1 & 54.7 & 64.1 & 70.5 & 64.1 \\
\hline Sometimes & 29.0 & 23.1 & 36.0 & 30.9 & 23.1 & 39.6 & 26.3 & 23.1 & 26.3 \\
\hline Often/always & 7.7 & 6.6 & 9.0 & 6.3 & 6.8 & 5.7 & 9.6 & 6.3 & 9.6 \\
\hline \multicolumn{10}{|l|}{ Parents understanding their issues (\%) } \\
\hline Often or always & 42.3 & 42.1 & 42.6 & 42.5 & 41.2 & 43.8 & 42.2 & 43.2 & 40.8 \\
\hline Sometimes & 32.2 & 32.5 & 31.8 & 32.4 & 36.0 & 28.6 & 31.9 & 28.4 & 36.6 \\
\hline Never or rarely & 25.4 & 25.4 & 25.6 & 25.1 & 22.8 & 27.6 & 25.9 & 28.4 & 22.5 \\
\hline \multicolumn{10}{|l|}{ Environmental factors } \\
\hline \multicolumn{10}{|l|}{ Nutritional status (\%) } \\
\hline Eutrophy & 78.0 & 76.1 & 80.1 & 76.8 & 73.7 & 80.2 & 79.5 & 79.1 & 80.0 \\
\hline Thinness/malnutrition & 3.4 & 2.9 & 4.0 & 4.1 & 3.5 & 4.7 & 2.5 & 2.2 & 2.9 \\
\hline Overweight/obesity & 18.6 & 21.0 & 15.9 & 19.1 & 22.8 & 15.1 & 18.0 & 18.6 & 17.1 \\
\hline Handwashing before meals (\%) & & & & & & & & & \\
\hline Often or always & 69.7 & 73.1 & 65.7 & 71.7 & 73.5 & 69.8 & 67.1 & 72.6 & 59.7 \\
\hline Sometimes/never/rarely & 30.3 & 26.9 & 34.3 & 28.2 & 26.5 & 30.2 & 32.9 & 27.4 & 40.3 \\
\hline Use of dental services & & & & & & & & & \\
\hline Oral health self-assessment (\%) & & & & & & & & & \\
\hline Very good/good & 63.0 & 70.1 & 54.5 & 64.9 & 67.2 & 62.3 & 60.5 & 73.7 & 43.1 \\
\hline Regular & 31.4 & 28.0 & 35.4 & 30.6 & 30.2 & 31.1 & 32.3 & 25.3 & 41.7 \\
\hline Bad/very bad & 5.7 & 1.9 & 10.1 & 4.5 & 2.6 & 6.6 & 7.2 & 1.0 & 15.3 \\
\hline The need for dental treatment (\%) & 48.1 & 38.4 & 59.5 & 46.8 & 39.6 & 54.7 & 49.7 & 36.8 & 66.7 \\
\hline Toothache in the last six months (\%) & 19.6 & 8.1 & 33.3 & 18.5 & 8.6 & 29.2 & 21.1 & 7.4 & 39.4 \\
\hline Dental consultation in the last year (\%) & & & & & & & & & \\
\hline Yes & 66.8 & 69.8 & 63.5 & 68.4 & 70.7 & 66.0 & 64.7 & 68.4 & 59.7 \\
\hline No & 33.2 & 30.3 & 36.5 & 31.5 & 29.3 & 34.0 & 35.3 & 31.6 & 40.3 \\
\hline
\end{tabular}


Table 1 (continued)

\begin{tabular}{|c|c|c|c|c|c|c|c|c|c|}
\hline \multirow[t]{3}{*}{ Variables } & \multicolumn{3}{|c|}{ Total sample } & \multicolumn{3}{|c|}{ Non-quilombola } & \multicolumn{3}{|c|}{ Quilombola } \\
\hline & \multirow[t]{2}{*}{$N(390)$} & \multicolumn{2}{|l|}{ Impact $^{\mathrm{a}}$} & \multirow[t]{2}{*}{$N(223)$} & \multicolumn{2}{|l|}{ Impact $^{a}$} & \multirow[t]{2}{*}{ n (167) } & \multicolumn{2}{|l|}{ Impact $^{a}$} \\
\hline & & No (212) & Yes (178) & & No (117) & Yes (106) & & No (95) & Yes (72) \\
\hline \multicolumn{10}{|l|}{ Oral health risk behaviour } \\
\hline \multicolumn{10}{|l|}{ Toothbrushing (\%) } \\
\hline More than 3 times a day or equal & 66.7 & 67.0 & 66.3 & 67.3 & 65.0 & 69.8 & 65.9 & 69.5 & 61.1 \\
\hline Less than 3 times a day & 33.3 & 33.0 & 33.7 & 32.7 & 35.0 & 30.2 & 34.1 & 30.5 & 38.9 \\
\hline No use of dental floss (\%) & 46.7 & 44.8 & 48.9 & 46.2 & 44.4 & 48.1 & 47.3 & 45.3 & 50.0 \\
\hline Regular consume of snacks (\%) & 35.1 & 33.0 & 37.6 & 33.2 & 32.5 & 34.0 & 37.7 & 33.7 & 43.1 \\
\hline Regular consume of soft drinks (\%) & 6.7 & 7.1 & 6.2 & 7.2 & 5.9 & 8.5 & 6.0 & 8.4 & 2.8 \\
\hline \multicolumn{10}{|c|}{ " $P$ value $<0.05$ calculated using X2 test (categorical variables) for the comparison between non-quilombola and quilombola samples } \\
\hline \multicolumn{10}{|c|}{ a Negative impact of oral health condition on the quality of life: No, absence of impact (total OIDP score $=0$ ); Yes, presence of impact (total OIDP score $\geq 1$ ) } \\
\hline \multicolumn{10}{|c|}{$\begin{array}{l}\text { b Age, Interquartile Range: Total Sample (total }=4.8 ; \text { impact: no }=4.5 ; \text { yes }=5.1 \text { ); Non-Quilombola (total }=4.9 ; \text { impact: } \text { no }=4.7 ; \text { yes }=5.0 \text { ); Quilombola }(\text { total }=4.6 \text {; } \\
\text { impact: } \text { no }=4.2 ; \text { yes }=4.2 \text { ) }\end{array}$} \\
\hline
\end{tabular}

samples were observed only in tooth brushing discomfort, which was reported by $14.4 \%$ and $7.6 \%$ of quilombola and non-quilombola adolescents, respectively (Fig. 2). The overall prevalence of at least one negative impact of oral health conditions on quality of life was $45.6 \%$, of which $47.5 \%$ was among non-quilombola adolescents and $43.1 \%$ was among quilombola adolescents. No significant difference in prevalence of at least one

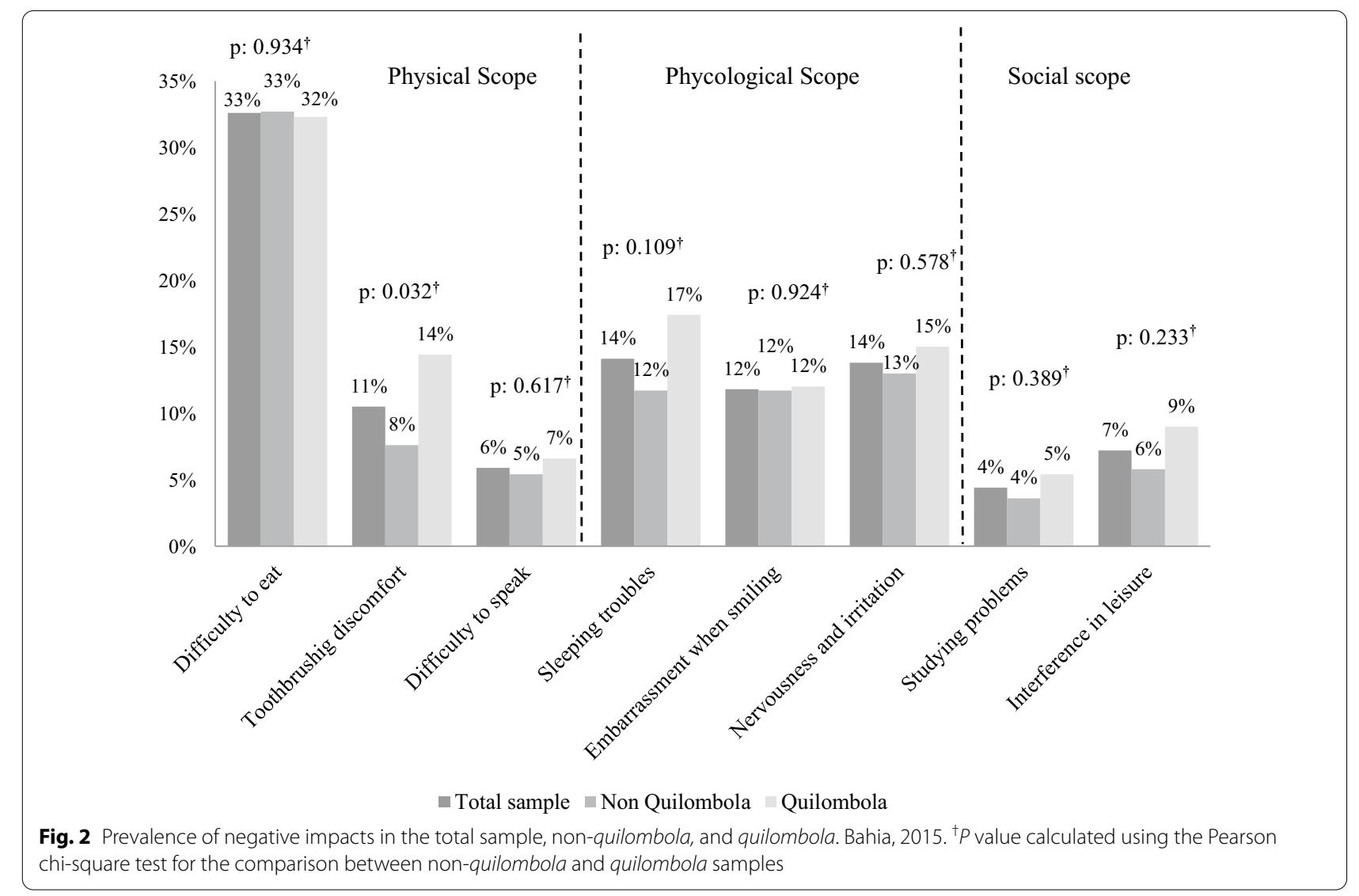


negative impact of oral health conditions on quality of life was found among quilombolas and non-quilombolas.

The prevalence of negative impacts of oral health conditions on quality of life was significantly higher among older adolescents, who reported feeling lonely sometimes over the past year, considered their oral health to be regular, bad, or very bad, and reported a need for dental treatment and the occurrence of toothache in the last 6 months (Table 2).

Among non-quilombola adolescents, the most prevalent negative impact was among those who felt lonely sometimes, needed dental treatment, and had toothache in the last 6 months. Among quilombolas, a significant positive relationship was found with age, better schooling, worse oral health self-assessment, the need for dental treatment, and occurrence of toothache in the last 6 months (Table 2).

After multiple analysis, the following factors were found to be independently associated with the prevalence of negative impact of oral health conditions on quality of life in the total sample: age $(\mathrm{PR}=1.04)$; feeling lonely sometimes $(\mathrm{PR}=1.42)$; oral health self-assessment as bad or very bad $(\mathrm{PR}=1.52)$; need for dental treatment $(\mathrm{PR}=1.33)$; and the occurrence of toothache in the last 6 months $(\mathrm{PR}=1.83)$ (Table 3$)$.

Among non-quilombolas, the prevalence of negative impact of oral health conditions on quality of life was independently associated with feeling lonely sometimes $(\mathrm{PR}=1.46)$ and the occurrence of toothache in the last 6 months $(\mathrm{PR}=1.75)$. Among quilombolas, the prevalence remained positively associated with age $(\mathrm{PR}=1.10)$, oral health self-assessment as bad or very bad $(\mathrm{PR}=1.91)$, need for dental treatment $(\mathrm{PR}=1.49)$, and the occurrence of toothache in the last 6 months $(\mathrm{PR}=1.83)$ (Table 3).

\section{Discussion}

The rural adolescents in this study, including quilombolas and non-quilombolas, presented a high prevalence of negative impact of oral health conditions on quality of life. Sociocultural factors and related to the need for dental treatment presented the strongest association with the occurrence of negative impact.

However, a higher prevalence of negative impact of oral health conditions on quality of life has previously been reported among 12-year-old adolescents who participated in research in another region of Brazil (58.1\%) [25], Italian pupils between 11 and 16 years of age (66.8\%) [6], rural and urban adolescents in Uganda (62.0\%) [5], and 12-year-old students in Sudan (54.6\%) [7]. Such differences can be attributed to the local epidemiologic patterns of oral diseases.

Difficulty eating was the impact most frequently reported by rural adolescents, as found in many other studies [2, 7, 25, 26]. Importantly, around $20 \%$ of the adolescents interviewed reported toothache in the past 6 months [11]. Therefore, it is reasonable to assume that the most prevalent negative impact is physical rather than psychological in nature [2]. In countries with a low occurrence of toothache, loss of teeth, or untreated caries, embarrassment when smiling is one of the most prevalent impacts, suggesting that the epidemiological profile influences the pattern of negative impacts of oral health conditions on quality of life $[2,6]$.

The quilombola and non-quilombola adolescents presented differences in the occurrence of tooth brushing discomfort. A previous study found that the two populations did not differ significantly as regards to other aspects related to oral health conditions, including toothache, oral health self-assessment, and need for dental treatment. However, differences in the use of dental services were found [11]. Therefore, given that quilombola adolescents had a lower prevalence of dental consultations at some point in their lives, and that tooth brushing is a technique that must be taught [27], it is acceptable to assume that different oral hygiene techniques can influence tooth brushing discomfort, as well as other oral clinical conditions not yet investigated.

The prevalence of at least one negative impact increased with age in the total and quilombola samples. Previous studies found a direct relation between dental cavities and increasing age during adolescence, which is a very risky period for oral and general health [28]. Therefore, poorer oral health conditions increase the probability of negative impact on quality of life among older adolescents [29].

In the present study, the adolescents who mentioned feeling lonely sometimes in the last 12 months presented a higher prevalence of negative impact of oral health conditions on daily life, except among quilombola adolescents. The feeling of loneliness was used as an indicator of the mental health status of adolescents. Studies have shown that individuals who had poor social support and who lived alone adopted fewer healthy preventive behaviours and had a higher prevalence of oral diseases, probably because they feel less motivated to perform self-care [30, 31].

The worst self-assessment for oral health and the perception of the need for dental treatment were associated with negative impact of oral health conditions on daily life in the total and quilombola samples. This relation was expected, as there is a match between clinical condition and self-perception of oral health, especially in the more painful and esthetical cases. Damage caused by oral problems negatively affect quality of life, self-esteem, and oral health perception [32,33]. 
Table 2 Prevalence, prevalence ratio and $95 \%$ confidence interval of negative impact of oral health condition on the quality of life for the total sample, quilombola and non-quilombola. Bahia, 2015

\begin{tabular}{|c|c|c|c|c|c|c|c|c|c|}
\hline \multirow[t]{2}{*}{ Variable } & \multicolumn{3}{|c|}{ Total sample } & \multicolumn{3}{|c|}{ Non-quilombola } & \multicolumn{3}{|c|}{ Quilombola } \\
\hline & $P(\%)^{\dagger}$ & PR & $95 \% \mathrm{Cl}$ & $P(\%)^{\dagger}$ & PR & $95 \% \mathrm{Cl}$ & $P(\%)^{\dagger}$ & PR & $95 \% \mathrm{Cl}$ \\
\hline \multicolumn{10}{|l|}{ Sociocultural factors } \\
\hline \multicolumn{10}{|l|}{ Economic status } \\
\hline B and C & 49.7 & 1.00 & - & 51.3 & 1.00 & - & 45.0 & 1.00 & - \\
\hline $\mathrm{D}$ and $\mathrm{E}$ & 43.1 & 0.87 & $0.70-1.08$ & 43.7 & 0.85 & $0.64-1.12$ & 42.5 & 0.94 & $0.63-1.41$ \\
\hline \multicolumn{10}{|l|}{ Gender } \\
\hline Female & 47.0 & 1.00 & - & 48.6 & 1.00 & - & 45.0 & 1.00 & - \\
\hline Male & 44.2 & 0.94 & $0.76-1.17$ & 46.5 & 0.96 & $0.72-1.26$ & 40.8 & 0.90 & $0.63-1.29$ \\
\hline Age & - & 1.05 & $1.01-1.09$ & - & 1.01 & $0.96-1.06$ & - & 1.10 & $1.03-1.17$ \\
\hline Schooling & - & 1.02 & $0.98-1.06$ & - & 0.99 & $0.94-1.04$ & - & 1.08 & $1.01-1.15$ \\
\hline \multicolumn{10}{|l|}{ Trying tobacco } \\
\hline No & 44.6 & 1.00 & - & 46.4 & 1.00 & - & 42.1 & 1.00 & - \\
\hline Yes & 65.0 & 1.46 & $1.03-2.05$ & 66.7 & 1.43 & $0.94-2.20$ & 62.5 & 1.48 & $0.84-2.62$ \\
\hline \multicolumn{10}{|l|}{ Trying illicit drugs } \\
\hline No & 45.7 & 1.00 & - & 47.2 & 1.00 & - & 43.6 & 1.00 & - \\
\hline Yes & 42.9 & 0.94 & $0.39-2.22$ & 60.0 & 1.27 & $0.61-2.64$ & 0.0 & - & - \\
\hline \multicolumn{10}{|l|}{ Practice of physical activities } \\
\hline Less than 300 min/week & 42.3 & 1.00 & - & 44.3 & 1.00 & - & 39.3 & 1.00 & - \\
\hline More or equal 300 min/week & 49.7 & 1.18 & $0.95-1.46$ & 51.5 & 1.20 & $0.85-1.71$ & 47.4 & 1.16 & $0.88-1.53$ \\
\hline \multicolumn{10}{|l|}{ Close friends } \\
\hline Up to 2 friends & 45.4 & 1.00 & - & 46.1 & 1.00 & - & 44.4 & 1.00 & - \\
\hline 3 or more & 45.7 & 1.00 & $0.75-1.34$ & 47.8 & 1.04 & $0.71-1.50$ & 42.7 & 0.96 & $0.61-1.53$ \\
\hline \multicolumn{10}{|l|}{ Family composition } \\
\hline Live with parents & 44.3 & 1.00 & - & 46.5 & 1.00 & - & 41.1 & 1.00 & - \\
\hline Do not live with parents & 48.4 & 1.09 & $0.87-1.37$ & 50.0 & 1.07 & $0.80-1.44$ & 46.7 & 1.13 & $0.80-1.62$ \\
\hline \multicolumn{10}{|l|}{ Feeling lonely } \\
\hline Never or rarely & 39.7 & 1.00 & - & 41.4 & & - & 37.4 & 1.00 & - \\
\hline Sometimes & 56.6 & 1.43 & $1.14-1.78$ & 60.8 & 1.46 & $1.12-1.93$ & 50.0 & 1.34 & $0.91-1.96$ \\
\hline Often/always & 53.3 & 1.34 & $0.93-1.94$ & 42.9 & 1.03 & $0.55-1.96$ & 62.5 & 1.67 & $1.06-2.63$ \\
\hline \multicolumn{10}{|l|}{ Parents understanding their issues } \\
\hline Often or always & 46.0 & 1.00 & - & 49.5 & 1.00 & - & 41.4 & 1.00 & - \\
\hline Sometimes & 45.2 & 0.98 & $0.76-1.27$ & 42.2 & 0.85 & $0.61-1.20$ & 49.1 & 1.18 & $0.80-1.75$ \\
\hline Never or rarely & 45.9 & 0.99 & $0.76-1.31$ & 52.7 & 1.07 & $0.77-1.47$ & 37.2 & 0.90 & $0.56-1.45$ \\
\hline \multicolumn{10}{|l|}{ Environmental factors } \\
\hline \multicolumn{10}{|l|}{ Nutritional status } \\
\hline Eutrophy & 47.5 & 1.00 & - & 50.3 & 1.00 & - & 43.7 & 1.00 & - \\
\hline Thinness/malnutrition & 53.8 & 1.13 & $0.67-1.90$ & 55.6 & 1.10 & $0.60-2.02$ & 50.0 & 1.14 & $0.42-3.11$ \\
\hline Overweight/obesity & 39.4 & 0.83 & $0.61-1.13$ & 38.1 & 0.76 & $0.50-1.15$ & 41.4 & 0.94 & $0.59-1.52$ \\
\hline \multicolumn{10}{|l|}{ Handwashing before meals } \\
\hline Often or Always & 43.0 & 1.00 & - & 46.2 & 1.00 & - & 38.4 & 1.00 & - \\
\hline Sometimes/never/rarely & 51.7 & 1.20 & $0.96-1.50$ & 50.8 & 1.09 & $0.82-1.47$ & 52.7 & 1.37 & $0.97-1.94$ \\
\hline \multicolumn{10}{|l|}{ Use of dental services } \\
\hline \multicolumn{10}{|l|}{ Oral health self-assessment } \\
\hline Very good/good & 39.6 & 1.00 & - & 45.8 & 1.00 & - & 30.7 & 1.00 & - \\
\hline Regular & 51.6 & 1.30 & $1.03-1.64$ & 48.5 & 1.06 & $0.78-1.44$ & 55.6 & 1.81 & $1.24-2.64$ \\
\hline Bad/very bad & 81.8 & 2.07 & $1.61-2.65$ & 70.0 & 1.53 & $0.98-2.38$ & 91.7 & 2.99 & $2.12-4.20$ \\
\hline \multicolumn{10}{|l|}{ The need for dental treatment } \\
\hline No & 35.6 & 1.00 & - & 40.7 & 1.00 & - & 28.6 & 1.00 & - \\
\hline
\end{tabular}


Table 2 (continued)

\begin{tabular}{|c|c|c|c|c|c|c|c|c|c|}
\hline \multirow[t]{2}{*}{ Variable } & \multicolumn{3}{|c|}{ Total sample } & \multicolumn{3}{|c|}{ Non-quilombola } & \multicolumn{3}{|c|}{ Quilombola } \\
\hline & $P(\%)^{\dagger}$ & PR & $95 \% \mathrm{Cl}$ & $P(\%)^{\dagger}$ & PR & $95 \% \mathrm{Cl}$ & $\overline{P(\%)^{\dagger}}$ & PR & $95 \% \mathrm{Cl}$ \\
\hline Yes & 56.7 & 1.59 & $1.27-1.99$ & 55.8 & 1.37 & $1.04-1.81$ & 57.8 & 2.02 & $1.37-2.98$ \\
\hline \multicolumn{10}{|l|}{ Toothache in the last 6 months } \\
\hline No & 37.8 & 1.00 & - & 41.4 & 1.00 & - & 32.8 & 1.00 & - \\
\hline Yes & 77.6 & 2.05 & $1.70-2.47$ & 75.6 & 1.82 & $1.43-2.33$ & 80.0 & 2.44 & $1.81-3.28$ \\
\hline \multicolumn{10}{|l|}{ Dental consultation in the last year } \\
\hline Yes & 43.5 & 1.00 & - & 46.0 & 1.00 & - & 39.8 & 1.00 & - \\
\hline No & 50.4 & 1.16 & $0.93-1.44$ & 51.4 & 1.12 & $0.84-1.49$ & 49.1 & 1.23 & $0.87-1.75$ \\
\hline \multicolumn{10}{|l|}{ Oral health risk behaviour } \\
\hline \multicolumn{10}{|l|}{ Toothbrushing } \\
\hline More than 3 times a day or equal & 45.3 & 1.00 & - & 49.3 & 1.00 & - & 40.0 & 1.00 & - \\
\hline Less than 3 times a day & 46.1 & 1.02 & $0.81-1.28$ & 43.8 & 0.89 & $0.65-1.21$ & 49.1 & 1.23 & $0.86-1.74$ \\
\hline \multicolumn{10}{|l|}{ Use of dental floss } \\
\hline Yes & 43.7 & 1.00 & - & 45.8 & 1.00 & - & 40.9 & 1.00 & - \\
\hline No & 47.8 & 1.09 & $0.88-1.36$ & 49.5 & 1.08 & $0.83-1.42$ & 45.6 & 1.11 & $0.78-1.58$ \\
\hline \multicolumn{10}{|l|}{ Regular consume of snacks } \\
\hline No & 43.9 & 1.00 & - & 47.0 & 1.00 & - & 39.4 & 1.00 & - \\
\hline Yes & 48.9 & 1.11 & $0.89-1.39$ & 48.6 & 1.03 & $0.77-1.38$ & 49.2 & 1.25 & $0.88-1.76$ \\
\hline \multicolumn{10}{|l|}{ Regular consume of soft drinks } \\
\hline No & 45.9 & 1.00 & - & 46.7 & 1.00 & - & 44.6 & 1.00 & - \\
\hline Yes & 42.3 & 0.92 & $0.58-1.46$ & 56.2 & 1.20 & $0.76-1.89$ & 20.0 & 0.44 & $0.13-1.57$ \\
\hline
\end{tabular}

$P R$ prevalence ratio, 95\% Cl 95\% confidence interval

${ }^{+} P$ : prevalence of negative impact of oral health condition on the quality of life

Table 3 Factors associated with the negative impact of oral health condition on quality of life, according to the regression model for the total sample, non-quilombola and quilombola. Bahia, 2015

\begin{tabular}{|c|c|c|c|c|c|c|}
\hline \multirow[t]{2}{*}{ Variable } & \multicolumn{2}{|c|}{ Total sample } & \multicolumn{2}{|c|}{ Non-quilombola } & \multicolumn{2}{|c|}{ Quilombola } \\
\hline & PR & $95 \% \mathrm{Cl}$ & PR & $95 \% \mathrm{Cl}$ & PR & $95 \% \mathrm{Cl}$ \\
\hline Age & 1.04 & $>1.00-1.08$ & - & - & 1.10 & $1.03-1.76$ \\
\hline \multicolumn{7}{|l|}{ Feeling lonely } \\
\hline Never or rarely & 1.00 & - & 1.00 & - & - & - \\
\hline Sometimes & 1.42 & $1.14-1.77$ & 1.46 & $1.12-1.93$ & - & - \\
\hline Often/always & 1.30 & $0.89-1.88$ & 1.03 & $0.55-1.96$ & - & - \\
\hline \multicolumn{7}{|c|}{ Oral health self-assessment } \\
\hline Very good/good & 1.00 & - & - & - & 1.00 & - \\
\hline Regular & 1.10 & $0.88-1.39$ & - & - & 1.40 & $0.97-2.02$ \\
\hline Bad/very bad & 1.52 & $1.16-1.99$ & - & - & 1.91 & $1.26-2.88$ \\
\hline \multicolumn{7}{|c|}{ The need for dental treatment } \\
\hline No & 1.00 & - & - & - & 1.00 & - \\
\hline Yes & 1.33 & $1.06-1.68$ & - & - & 1.49 & $1.01-2.19$ \\
\hline \multicolumn{7}{|c|}{ Toothache in the last 6 months } \\
\hline No & 1.00 & - & 1.00 & - & 1.00 & - \\
\hline Yes & 1.83 & $1.51-2.22$ & 1.75 & $1.37-2.24$ & 1.83 & $1.32-2.52$ \\
\hline
\end{tabular}

$P R$ prevalence ratio, 95\% Cl 95\% confidence interval 
Toothache is an important factor associated with the negative impact of oral health conditions on quality of life $[2,3,7,25]$. In the present study, both the quilombola and non-quilombola adolescents who had toothache in the previous 6 months had a higher prevalence of negative impacts. Toothache is considered as an indicator of the prevalence of carious lesions and is closely associated with negative impact of oral health conditions on the quality of life [34]. Various studies have reported an inverted correlation between the number of teeth without cavities and the negative impact on daily activities due to oral problems $[2,21,35]$. As toothache is a common health problem around the world, its monitoring could be used as a strategy for surveillance of the population's oral health. The prevalence of toothache in adolescents is directly related to the quality of national oral health services, and the reduction of its occurrence is part of the Global Goals for Oral Health 2020 of the World Health Organization [36, 37].

Among the associations that were not observed in the present study, gender and economic status stand out, which were shown in other studies with Brazilian urban adolescents [2, 18, 29]. These studies found a higher prevalence of a negative impact from oral conditions on quality of life among girls, which the authors explained could be related to greater self-criticism regarding dental appearance and low self-esteem among girls and/or stereotypes of masculinity which contributed to greater resistance to pain among boys $[2,18,29]$. Thus, cultural distinctions related to gender may contribute to this association not being observed among rural adolescents. Regarding economic status, the majority of the population was in the lowest level. This homogeneity may have contributed to the lack of association with this variable in the study.

Moreover, differences in the occurrence of at least one negative impact of oral conditions on quality of life were not found between quilombola and non-quilombola adolescents, despite differences in associated factors. Quilombola adolescents face social and health inequities, including more difficult access to dental services [11]. Geographical distance, transportation from quilombola communities to health services, the restricted schedule of health services, the prioritisation of services to other population groups, and the need of a legal representative for dental services for adolescents all make it difficult for the oral health of these adolescents to receive due attention [38].

Despite its relevance for the awareness of oral health conditions' impact on the lives of quilombola and non-quilombola rural adolescents, the present study has some limitations. These are due to the lack of information on the clinical conditions of adolescents and the impossibility of inferring the temporality of some observed associations because of the cross-sectional nature of the study. Moreover, because the sample was not primarily designed to test differences between quilombolas and non-quilombolas, there may not have been enough sampling power for some variables.

\section{Conclusion}

The negative impact of oral health conditions on quality of life was reported by a great number of the quilombola and non-quilombola rural adolescents. The factors associated with the prevalence of occurrence of at least one negative impact of oral conditions on quality of life were different between quilombola and non-quilombola adolescents, reinforcing the need to treat quilombola adolescents as a separate group.

The characteristics related to dental care, such as worst oral health self-assessment, perception of the need for dental treatment, and occurrence of toothache, were associated with occurrence of negative impact of oral health conditions on daily life. This result reinforces the need to improve attention and support for the oral health of quilombola and non-quilombola rural adolescents through preventive measures, monitoring, and treatment of oral diseases. It is also necessary to incorporate strategies that take into consideration the social context in which adolescents live that may influence their oral healthcare [19].

In addition to improving conditions for quilombola and non-quilombola adolescents to access dental services, we highlight the need for public policies to improve living conditions in rural communities, such as permanent and adequate access to fluoridated water. Moreover, intersectoral health education activities involving adolescents and their families should be carried out in partnerships among health services, schools, and community organizations. These activities should focus on cultural aspects, popular knowledge, and strengthen the concept of oral health as a basic human right and not as a privilege.

Oral health policies in Brazil continue to focus more heavily on oral rehabilitation and tooth extraction than on preventive approaches to oral health. Oral health transcends odontology. Therefore, oral health initiatives need to be comprehensive e and intersectoral to allow for holistic attention to health that considers the needs of different population groups [32]. 


\section{Abbreviations}

PR: Prevalence ratio; OIDP: Oral impact on daily performance; BMI: Body mass index.

\section{Acknowledgements}

Thank you to the rural families and adolescents, community agents, and other professionals at Estrategia de Saude da Familia, whose contributions were crucial for the completion of this study.

\section{Authors' contributions}

All authors participated in the study design; performed data acquisition, analysis, and interpretation; drafted, revised, and approved the manuscript; and agreed to submission.

\section{Funding}

This work was funded by a grant from the Fundacao de Amparo a Pesquisa do Estado da Bahia (FAPESB).

\section{Availability of data and materials}

The datasets used and analysed in the current study are available upon request to the corresponding author.

\section{Ethics approval and consent to participate}

The study received research ethics committee approval (file number 639.966) from the Comite de Etica em Pesquisa com seres humanos do Instituto Multidisciplinar em Saude da Universidade Federal da Bahia.

\section{Consent for publication}

Not applicable.

\section{Informed consent}

Informed consent was obtained from all participants included in the study.

\section{Competing interests}

The authors declare no competing interest.

Received: 29 October 2019 Accepted: 16 September 2020

Published online: 29 September 2020

\section{References}

1. Petersen PE, WHO Oral Health Programme. The world oral health report 2003: continuous improvement of oral health in the 21st century - the approach of the WHO Global Oral Health Programme/Poul Erik Petersen. World Health Organization. 2003. https://apps.who.int/iris/handle/10665 /68506. Accessed 12 Mar 2020.

2. Peres KG, Cascaes AM, Leão ATT, Côrtes MIS, Vettore MV. Aspectos sociodemográficos e clínicos da qualidade de vida relacionada à saúde bucal em adolescentes. Revista de Saúde Pública. 2013;47:3.

3. Barbosa TB, Junqueira SR, Frias AC, Araújo ME. Interferência da saúde bucal em funções biológicas e sociais segundo a percepção de adolescentes brasileiros. Braz Res Pediatr Dent Integr Clin. 2013;13:2.

4. Tesh FC, Oliveira BH, Leão A. Mensuração do impacto dos problemas bucais sobre a qualidade de vida de crianças: aspectos conceituais e metodológicos. Cadernos de Saúde Pública. 2007;23:11.

5. Astrom AN, Okullo I. Validity and realiability of the Oral Impacts on Daily Performance (OIDP) frequency scale: a cross-sectional study of adolescentes in Uganda. BMC Oral Health. 2003;3:5.

6. Bianco A, Fortunato L, Nobile CGA, Pavia M. Prevalence and determinants of oral impacts on daily performance: results from a survey among school children in Italy. Eur J Publ Health. 2009;20:5

7. Nurelhuda NM, Ahmed MF, Trovik TA, Astrom AN. Evaluation of oral health-related quality of life among Sudanese schoolchildren using Child-OIDP inventory. Health Qual Life Outcomes. 2010;8:152.

8. Silveira MF, Marôco JP, Freire RS, Martins AMEBL, Marcopito LF. Impacto da saúde bucal nas dimensões físicas e psicossocial: uma análise através da modelagem com equações estruturais. Cadernos de Saúde Pública. 2014;30:6.
9. Sousa BC, Teixeira CSS, Curvelo MHS, Souzas R, Bezerra VM, Silva EKP, et al. Hábitos alimentares de adolescentes quilombolas e não quilombolas da zona rural do semiárido baiano. Ciência Saúde Coletiva. 2019:24:2.

10. Silva EKP, Medeiros DS, Martins PC, Sousa LA, Lima GP, Rêgo MAS, et al. Insegurança alimentar em comunidades rurais no Nordeste brasileiro: faz diferença ser quilombola? Cad Saúde Pública. 2017;33(4):e00005716.

11. Silva EKP, Santos PR, Chequer TPR, Melo CMA, Santana KC, Amorim MM, et al. Saúde bucal de adolescentes rurais quilombolas e não quilombolas: um estudo dos hábitos de higiene e fatores associados. Ciência Saúde Coletiva. 2018;23:9.

12. Moreira RS, Nico LS, Tomita NE. A relação entre o espaço e a saúde bucal coletiva: por uma epidemiologia georreferenciada. Ciência Saúde Coletiva. 2007:12:1.

13. Brasil. Ministério da Saúde. Secretaria de Atenção à Saúde. Secretaria de Vigilância em Saúde. SB Brasil. Pesquisa Nacional de Saúde Bucal: resultados principais. Brasília: Ministério da Saúde; 2010. p. 2012.

14. Instituto Brasileiro de Geografia e Estatística (IBGE). Questionário PENSE 2012. 2012. https://biblioteca.ibge.gov.br/bibliotecacatalogo?view=detal hes\&id=52908. Accessed 18 Jun 2014.

15. Pesquisa Nacional de Saúde - PNS. Questionário do Domicílio. 2013. https ://www.pns.icict.fiocruz.br/arquivos/Domiciliar/Modulo\%2520A-PNS.pdf. Accessed 18 Jun 2014.

16. Adulyanon S, Sheiham A. Oral impacts on daily. In: Slade GD, editor. Measuring oral health and quality of life. Chapel Hill: University of North Carolina, Dental Ecology; 1997.

17. Bernabé E, Tsakos G, Oliveira CM, Sheiham A. Impacts on daily performances attributed to malocclusions using the condition-specific feature of the Oral Impacts on Daily Performances Index. Angle Orthod. 2008;78(2):241-7. https://doi.org/10.2319/030307-111.1.

18. Cunha IP, Pereira AC, Frias AC, Vieira V, Meneghim MC, Batistan MJ, et al. Social vulnerability and factors associated with oral impact on daily performance among adolescents. Health Qual Life Outcomes. 2017;15:173.

19. Alwadi MAM, Vettore MV. Are school and home environmental characteristics associated with oral health-related quality of life in Brazilian adolescents and young adults? Commun Dent Oral Epidemiol. 2017:45(4):35664. https://doi.org/10.1111/cdoe.12298.

20. Cortes MIS, Marcenes W, Sheiham A. Impact of traumatic injuries to the permanent teeth on the oral health-related quality of life in 12-14-yearold children. Commun Dent Oral Epidemiol. 2002;30:193-8.

21. Petersen PE. Sociobehavioural risk factors in dental caries -international perspectives. Commun Dent Oral Epidemiol. 2005;33:274-9.

22. Associação Brasileira de Empresas de Pesquisa. Critério de classificação econômica Brasil. 2017. https://www.abep.org/criterio-brasil. Accessed 19 April 2017.

23. Brasil. Ministério da Saúde. Orientações para coleta e análise de dados antropométricos em serviços de saúde: norma técnica do sistema de Vigilância Alimentar e Nutricional - SISVAN. Brasília: Ministério da Saúde, 2011. (Série G. Estatística e Informação em Saúde). https://dab.saude.gov. br/portaldab/biblioteca.php?conteúdo=publicacoes/orientacoes_colet a_analise_dados_antropometricos. Accessed 18 Mar 2017.

24. Lee J, Tan CS, Chia KS. A practical guide for multivariate analysis of dichotomous outcomes. Ann Acad Med Singap. 2009;38:714-9.

25. Peres KG, Peres MA, Araújo CLP, Menezes AMB, Hallal PC. Social and dental status along the life course and oral health impacts in adolescents: a population-based birth cohort. Biomed Cent. 2009;7:95.

26. Castro RAL, Portela MC, Leão AT, Vasconcellos MTL. Oral health-related quality of life of 11- and 12-year-old public school children in Rio de Janeiro. Commun Dent Oral Epidemiol. 2011. https://doi.org/10.111 1/j.1600-0528.2010.00601.x.

27. Brasil. Ministério da Saúde. Secretaria de Atenção à Saúde; Departamento de Atenção Básica. Coordenação Nacional de Saúde Bucal. Diretrizes da Política Nacional de Saúde Bucal. 2004. https://bvsms.saude.gov.br/bvs/ publicacoes/politica_nacional_brasil_sorridente.pdf. Accessed 18 May 2017.

28. Silva Junior IF, Aguiar NL, Barros RC, Arantes DC, Nascimento LS. Saúde bucal do adolescente: revisão de literatura. Revista Adolescência e Saúde. 2016;13(supl. 1):95-103

29. Fonseca RCL, Antunes JLF, Cascaes AM, Bomfim RA. Analysis of the combined risk of oral problems in the oral health-related quality of life of Brazilian adolescents: multilevel approach. Clin Oral Invest. 2020;24(2):857-66. https://doi.org/10.1007/s00784-019-02976-z. 
30. Dolic M, Bailer J, Staehle HJ, Eickholz P. Psychosocial factors as risk indicators of periodontitis. J Clin Periodontol. 2005:32:1134-40.

31. Davoglio RS, Aerts DRGC, Abegg C, Freddo SL, Monteiro L. Fatores associados a hábitos de saúde bucal e utilização de serviços odontológicos entre adolescentes. Cadernos de Saúde Pública. 2009;25:3.

32. Narvai PC, Frazão P. Saúde Bucal no Brasil: Muito Além do Céu da Boca. Rio de Janeiro: Editora Fiocruz; 2008

33. Baker SR, Mat A, Robinson PG. What psychosocial factors influence adolescents oral health? J Dent Res. 2010;89:11.

34. Freire MCM, Leles CR, Sardinha LMV, Junior MP, Malta DC, Peres MA. Dor dentaria e fatores associados em adolescentes brasileiros: Pesquisa Nacional de Saude do Escolar (PeNSE), Brasil, 2009. Cadernos de Saúde Pública. 2012;28(Supp.):S133-S145145.

35. Biazevic MGH, Rissotto RR, Michel-Crosato E, Mendes LA, Mendes MOA. Relationship between oral health and its impact on quality of life among adolescents. Braz Oral Res. 2008;22:1.
36. Hobdell M, Petersen PE, Clarkson J, Newell J. Global goals for oral health 2020. Int Dent J. 2003;53:285-8.

37. Noro LRA, Roncalli AG, Mendes Júnior FIR, Lima KC, Teixeira AKM. Toothache and social and economic conditions among adolescents in Northeastern Brazil. Ciência Saúde Coletiva. 2014;19(1):105-14.

38. Santana KC, Teles N, Oliveira MHB, Medeiros DS. Direito à saúde: adolescentes quilombolas em comunidades rurais de Vitória da Conquista (BA). In: Oliveira MHB, Erthal RMC, Vianna MB, Matta JLJ, Vasconcellos LCF, Bonfatti RJ, organizadores. Direitos humanos e saúde: construindo caminhos, viabilizando rumos, vol 1. Rio de Janeiro: Cebes, 2017, pp 53-6.

\section{Publisher's Note}

Springer Nature remains neutral with regard to jurisdictional claims in published maps and institutional affiliations.
Ready to submit your research? Choose BMC and benefit from:

- fast, convenient online submission

- thorough peer review by experienced researchers in your field

- rapid publication on acceptance

- support for research data, including large and complex data types

- gold Open Access which fosters wider collaboration and increased citations

- maximum visibility for your research: over 100M website views per year

At BMC, research is always in progress.

Learn more biomedcentral.com/submissions 